\title{
Establishment of the entomopathogenic fungus Beauveria bassiana as an endophyte in Capsicum annuum and its effects on the aphid pest Myzus persicae (Homoptera: Aphididae)
}

\author{
Natalia Allegrucci ${ }^{1 *}$, Maria Silvana Velazquez ${ }^{1}$, María Leticia Russo ${ }^{1}$, Maria Florencia Vianna ${ }^{1}$, \\ Camila Abarca ${ }^{1} \&$ Ana Clara Scorsetti ${ }^{1}$ \\ 1. Institute of Botany Carlos Spegazzini, Facultad de Ciencias Naturales y Museo, Universidad Nacional de La Plata \\ (FCNyM-UNLP), 53 \# 477, 1900 La Plata, Buenos Aires, Argentina; nataliaallegrucci@yahoo.com, mariasilvana- \\ velazquez@gmail.com, leticia_russo@hotmail.com, florvianna@yahoo.com.ar, camila.abrc@gmail.com, anacs- \\ corsetti@yahoo.com \\ * Correspondence
}

Received 26-III-2020. C Corrected 08-VI-2020. Accepted 06-VIII-2020.

\begin{abstract}
Introduction: Entomopathogenic fungi have been used as biological control agents of insect pests and have demonstrated a promising ability to colonize as endophytes a wide range of plant species. Objective: The aims of this study were to evaluate, in pepper plants, the most effective Beauveria bassiana inoculation techniques. In order to evaluate the presence of natural endophytes and its interaction with $B$. bassiana. Also to assess the effect of B. bassiana on the aphid Myzus persicae pepper leaf feeding preference and growth. Methods: Three inoculation techniques were evaluated: leaf spraying, seed immersion and root dipping. The pepper plants were inoculated with a conidia suspension adjusted to $1 \times 10^{8}$ conidia $/ \mathrm{ml}$. The presence of $B$. bassiana in the seedlings was evaluated at 7, 15 and 28 days after inoculation. Results: We found significant statistical differences between inoculation techniques. Foliar spraying showed the highest $B$. bassiana colonization frequency. The natural endophytes presented higher presence in the treatments in which B. bassiana had a low presence. This might indicate the occurrence of antifungal activity that interferes with the establishment of the entomopathogen in pepper tissues. We did not find statistical differences between inoculated and control pepper leaves with regard to the mortality and reproduction of the aphid pest $M$. persicae. However, the inoculation with B. bassiana showed a tendency to increase the mortality of adults and to decrease the offspring (nymphs). We did not find significant differences in the feeding preference between inoculated and control leaves, although there was a higher number of individuals on control leaves compared to those inoculated. Conclusions: The strain B. bassiana LPSC 1067 was established effectively as an endophyte in the pepper tissues. The most effective inoculation technique was leaf spraying. We did not find differences of statistical significance with regard to the mortality and reproduction of the aphid pest $M$. persicae. However, the inoculation with $B$. bassiana showed a tendency to increase the mortality of adults and to decrease the offspring (nymphs). Future studies evaluating the indirect effects of endophytic entomopathogens on both plants and herbivorous insects are needed to further explore their potential use in the management of insect pests.
\end{abstract}

Key words: endophytic fungi; inoculation techniques; biological control agents; aphid pest.

Allegrucci, N., Velazquez, M.S., Russo, M.L., Vianna, M.F., Abarca, C., \& Scorsetti, A.C. (2020). Establishment of the entomopathogenic fungus Beauveria bassiana as an endophyte in Capsicum annuum and its effects on the aphid pest Myzus persicae (Homoptera: Aphididae). Revista de Biología Tropical, 68(4), 1084-1094.

Entomopathogenic fungi are considered important natural pathogens of arthropods and are used mainly for the biological control of insect pests. These fungi have demonstrated a promising ability to colonize endophytically a wide variety of plant species (Wilson, 1995). This feature provides multiple benefits to plants that include double protection against 
insect pests and plant diseases (Jaber \& Ownley. 2018), and growth promotion (Jaber \& Enkerli, 2017). The presence of entomopathogenic fungi naturally occurring as endophytes also demonstrates that they have complex life cycles, which can be completed either in the soil, invertebrate organisms or plants. Besides the taxonomy and phylogeny of fungal entomopathogens, most research has focused on their development as biological control agents (Vega, 2008). Recently studies have examined their biology, including the survival and interactions outside the host insects (Mantzoukas, Chondrogiannis, \& Grammatikopoulos, 2015; Manoussopoulos, Mantzoukas, Lagogiannis, Goudoudaki, \& Kambouris, 2019; Mantzoukas \& Lagogiannis, 2019). Beauveria bassiana (Balsamo) Vuillemin (Ascomycota: Hypocreales) is an entomopathogenic fungus widely distributed worldwide (Ownley et al., 2008). This fungus has been isolated as a naturally occurring endophyte from different plant species (Vega, 2008). In addition, it has been introduced artificially by using different techniques in corn (Wagner \& Lewis, 2000; Russo, Pelizza, Cabello, Stenglein, \& Scorsetti, 2015), soybean (Russo et al., 2018), potato (Jones, 1994), cotton (Jones, 1994), jimsonweed (Jones, 1994), tomato (Allegrucci, Velazquez, Russo, Perez, \& Scorsetti, 2017), date palm (Gomez-Vidal, Lopez-Llorca, Jansson, \& Salinas, 2006), banana (Akello, Dubois, Gold, Coyne, Nakavuma, \& Paparu, 2007), coffee (Posada, Aime, Peterson, Rehner, \& Vega, 2007) and cocoa (Posada \& Vega, 2005), with the aim of evaluating its potential for the biocontrol of insect pests.

Species of the genus Capsicum are likely the most consumed peppers worldwide (Rozin \& Schiller, 1980). Capsicum annuиm L. is one of the five economically most profitable species in the world (Perry et al., 2007). The aphid Myzus persicae (Hemiptera; Aphididae) has a worldwide distribution and infests more than 40 plant families (Blackman \& Eastop, 2000). This aphid is one of the main pests of C. annuum and has the ability to transmit more than 100 plant viruses and cause direct damages in pepper plants. In many crops, its control is based almost exclusively on the application of insecticides and, as a result, this species has developed multiple resistance to many chemical classes, including organophosphates, carbamates, and pyrethroids (Devonshire et al., 1998). Laboratory studies have shown that some strains of $B$. bassiana are highly virulent against $M$. persicae and are able to infect almost $95 \%$ of the aphids by direct application (Chen, Li, \& Feng, 2008).

The aims of this study were i) to evaluate the most effective inoculation techniques, (leaf spraying, seed immersion and root dipping) for the endophytic inoculation of $B$. bassiana (LPsC 1067) in pepper plants. ii) To evaluate the presence of natural endophytes in inoculated leaf and its interaction with $B$. bassiana. iii) To assess the effect of $B$. bassiana on $M$. persicae pepper leaf feeding preference and the growth of the aphid pest.

\section{MATERIALS AND METHODS}

Fungal isolate: The strain $B$. bassiana LPSC 1067 (GenBank accession number KF500409), isolated from Coleoptera, Coccinelidae, was obtained from the culture collection of "Instituto Spegazzini" (Universidad Nacional de La Plata), La Plata, Buenos Aires, Argentina. The selection of this fungal strain was based on its effectiveness in laboratory tests against other insect pests common in Argentina (Pelizza et al., 2012) and for its endophytic capacity previously evaluated on other crops of agronomic importance (Allegrucci et al., 2017).

Fungal suspension: Conidia were obtained from 14 day cultures grown on potato dextrose agar (PDA, Britania S.A., Buenos Aires, Argentina) at $25{ }^{\circ} \mathrm{C}$ in the dark. The conidia were harvested with disposable cell scrapers (Fisherbrand ${ }^{\circledR}$ ) and placed into test tubes containing $0.01 \%(\mathrm{v} / \mathrm{v})$ Tween 80 (polyoxyethylene sorbitan monolaurate solution, Merck $\left.^{\circledR}\right)$. The suspensions were vortexed for $2 \mathrm{~min}$ and then filtered through four layers 
of sterile muslin. The conidial concentration was determined using a Neubauer hemocytometer and adjusted to $1 \times 10^{8}$ conidia/ml (Gurulingappa, Sword, Murdoch, \& McGee, 2010). To evaluate the conidial viability before each experiment, $0.3 \mathrm{ml}$ of each dilution was placed onto a slide with a thin layer of APG culture medium (Goettel \& Inglis, 1997). The slides were incubated in a humid chamber at 25 ${ }^{\circ} \mathrm{C}$ in the dark for $24 \mathrm{~h}$. Afterward, the slides were examined under the optical microscope. Conidia were considered germinated when the germ tube had at least the same diameter as the spore. This germination test was performed with three repetitions for each suspension to standardize the viability evaluations. In all cases, the suspensions used presented conidia viability greater than $95 \%$.

Host plants: Pepper seeds (C. annuum L) were obtained from organic crops nearby the city of La Plata, Buenos Aires province,

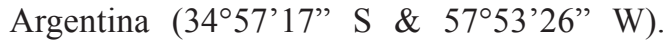
None of these seeds received previous chemical treatment. To ensure the absence of fungi on their surface, seeds were surface-sterilized by placing them in $70 \%$ ethanol for $2 \mathrm{~min}$, washed in sterile distilled water, then submerged in 0.5 $\%$ sodium hypochlorite for $1 \mathrm{~min}$ and rinsed again in sterile distilled water (Brownbridge, Reay, Nelson, \& Glare, 2012). Thereafter, the seeds were left to dry for $30 \mathrm{~min}$ on sterile filter paper. Half of the seeds were used for seed inoculation and the other half was planted for the application of foliar spraying and root dipping techniques after the emergence of the seedlings. The seeds were placed for germination in plastic pots with $86 \mathrm{~g}$ of an equally ground mixture of perlite, vermiculite, and soil $(1: 1: 1)$. Prior to use, the mixture was tyndallized in an autoclave for one hour on three consecutive days. Seedlings were maintained in a greenhouse at $25{ }^{\circ} \mathrm{C}$, with $70 \%$ relative humidity and a 12:12 LD photoperiod by the use of $400 \mathrm{nmol} \cdot \mathrm{m}^{-2} \cdot \mathrm{s}^{-1}$ cold light lamps.

Inoculation techniques: For seed inoculation technique, $10 \mathrm{~g}$ of seeds were immersed in $10 \mathrm{ml}$ of $B$. bassiana conidial suspension $0.01 \%(\mathrm{v} / \mathrm{v})$ Tween $80\left(1 \times 10^{8}\right.$ conidia $\left.\mathrm{ml}^{-1}\right)$ for $24 \mathrm{~h}$, according to the methodology of Brownbridge et al. (2012). The seeds were left to dry on sterile filter paper in a laminar flow chamber for $30 \mathrm{~min}$, then planted in pots at a $4 \mathrm{~cm}$ depth and maintained in a greenhouse at $25{ }^{\circ} \mathrm{C}$ with a 12:12 LD photoperiod. Control seeds were immersed in a conidial-free solution of $0.01 \%$ Tween 80 . In the case of foliar spraying, the leaves of pepper plants of $30 \mathrm{~cm}$ height were sprayed with $3 \mathrm{ml}$ of a $B$. bassiana conidia suspension $\left(1 \times 10^{8}\right.$ conidia $\left.\mathrm{ml}^{-1}\right)$ using a $30 \mathrm{ml}$ sterile glass manual sprayer (Posada et al. 2007). To prevent the conidia runoff into the ground, the upper part of each pot was covered with aluminium foil (Posada et al. 2007). Control plants were sprayed with a conidialfree solution of $0.01 \%$ Tween 80 . For root dipping, each seedling was removed from the pot and rinsed three times with sterile distilled water. The tips of the roots were cut for better absorption and each root seedling was placed individually in test tubes with $2 \mathrm{ml}$ of $B$. bassiana conidial suspension $\left(1 \times 10^{8}\right.$ conidia $\left.\mathrm{ml}^{-1}\right)$, according to the methodology of Akello et al. (2007). Each tube was covered with aluminium foil to prevent damage from UV rays. The roots of control plants were immersed in sterile distilled water. Tubes with both inoculated and control seedlings were incubated at $25{ }^{\circ} \mathrm{C}$ in the dark with $80 \%$ relative humidity for 24 $\mathrm{h}$. Then, both inoculated and control seedlings were placed on sterile filter paper until they were completely dried and replanted in the same pots. The seedlings in all the treatments were irrigated as required and maintained in a greenhouse at $25{ }^{\circ} \mathrm{C}$, with $70 \%$ relative humidity and a 12:12 LD photoperiod. Thirty replicates and 30 controls were prepared for each inoculation technique.

Evaluation of the presence of $B$. bassiana, natural endophytes and antifungal activity in vitro: For each inoculation technique, the presence of $B$. bassiana in the seedlings was evaluated at 7, 15 and 28 days after inoculation. One leaf was chosen randomly 
from each plant and superficially disinfected by the immersion in $70 \%$ ethanol for $2 \mathrm{~min}$, followed by $0.5 \%$ sodium hypochlorite for $2 \mathrm{~min}$ and rinsed with sterile distilled water (Arnold, Maynard, \& Gilbert, 2001). Disinfection was verified by inoculating $100 \mathrm{ml}$ of water from the last rinse of each sample onto a Petri dish with PDA culture medium. In addition, subsamples of surface-sterilized leaves were cultured in PDA plates to determine if the residual conidia retained the germinative potential (Gurulingappa et al. 2010). Leaves were dried on sterile paper under laminar flow chamber and their edges were cut to eliminate the dead tissue resulting from the sterilization process. For every sample six leaf fragments of approximately $1 \mathrm{~cm}^{2}$ of each of the 30 inoculated and control seedlings for each inoculation technique were used, totalizing 180 plants and 1080 leaf fragments examined. Leaf fragments were cut using a sterile scalpel and placed onto Petri dishes with $20 \mathrm{~mL}$ of PDA medium with 2 $\mathrm{mL}$ of antibiotics $(0.5 \mathrm{~g}$ streptomycin and 0.25 chloramphenicol/200 mL).

The presence or absence of $B$. bassiana in the leaf fragments was recorded after 10 days of incubation at $25^{\circ} \mathrm{C}$ and expressed as the frequency of colonization (number of colonized leaf fragments/ total number of leaf fragments) $\times 100$ (number of colonized leaf fragments $=$ a fragment with one $B$. bassiana colony, Petrini \& Fisher, 1986). In the inoculated leaf fragments, was also recorded, isolated and identified the endophytic fungi that naturally occurred in pepper leaves, with the purpose of determining the existence of antifungal activity among them and $B$. bassiana under laboratory conditions. The endophytic fungi were isolated and identified by traditional taxonomy (Domsch, Gams, \& Anderson, 2007), examined with a Wild M8 stereo microscope and a Dialux 20 Leitz microscope. To evaluate the antifungal activity, in vitro tests were carried out using the dual culture method (Paul, Deng, Sang, Choi, \& Yu, 2012). The species of natural endophytes and B. bassiana LPSc 1067 were individually cultured on APG medium and incubated at $25{ }^{\circ} \mathrm{C}$ for 4 days. Afterward, the agar disks (5 $\mathrm{mm}$ diam.) with mycelium of each species were cut and placed, one disk of endophyte and one of entomopathogen at a distance of $6 \mathrm{~cm}$ from each other on a Petri dish with APG culture medium. Controls were performed for each pair of endophyte $B$. bassiana. The antifungal activity was evaluated by measuring the distance of the inhibition zone between the endophyte and the entomopathogen using the following scale (Taechowisan, Peberdy, \& Lumyong, 2003): $+++\geq 20 \mathrm{~mm}$ (strong activity), $++=11-19 \mathrm{~mm}$ (moderate activity); 2-10 $\mathrm{mm}$ (low activity) and - $=0 \mathrm{~mm}$ (no activity).

Effect of $B$. bassiana as an endophyte on the growth, reproduction and feeding preference of Myzus persicae: Colonies of $M$. persicae were initiated with clones supplied by the Faculty of Agricultural and Forestry Sciences (Universidad Nacional de La Plata, Buenos Aires, Argentina). Aphids were reared on peppers plants cultivated in pots inside cages placed in a greenhouse with a cycle of $12 \mathrm{~h}$ light $\left(25^{\circ} \mathrm{C}\right) / 12 \mathrm{~h}$ dark $\left(20^{\circ} \mathrm{C}\right)$. To evaluate the effect of $B$. bassiana on the growth and reproduction of $M$. persicae, young pepper leaves inoculated with the foliar spraying technique were cut seven days before the beginning of the tests. The inoculated leaves were surface-sterilized with $70 \%$ ethanol, sodium hypochlorite and sterile distilled water (Gurulingappa et al., 2010). Subsequently, the leaves were placed individually in sterile 500 $\mathrm{ml}$ containers with $3 \%$ water agar in their base. Ten third-instar nymphs of $M$. persicae were transferred to the surface of each leaf using a brush of fine camel hair. The containers were maintained in a culture chamber with $12 \mathrm{~h}$ light at $25{ }^{\circ} \mathrm{C} / 12 \mathrm{~h}$ night at $20^{\circ} \mathrm{C}$. Fifteen repetitions of each inoculated and control leaves were made. Ten days after the beginning of the tests, the number of surviving adults and the number of nymphs of the next generation were recorded. The presence of the endophyte in the plants used for the bioassay was verified three days after inoculation. One leaf was chosen randomly from each plant and superficially 
disinfected (Arnold et al., 2001), then leaf fragments were cut and placed onto Petri dishes with PDA and antibiotics.

To evaluate the feeding preference of $M$. persicae, Petri dishes with moist filter paper (moist chambers) were prepared, in which two leaves of pepper of equal size were placed, one inoculated by leaf spraying three days before the beginning of the test and one non-inoculated (control). In each dish, three adult aphids were placed at the same distance between the two leaves. After $24 \mathrm{~h}$, the number of aphids that fed on each leaf were recorded. The aphids that were not on any leaf or had the same number of individuals on each leaf were not considered for the counting (Crawford, Land, \& Rudgers, 2010).

Data analyses: The analysis of variance (ANOVA) parametric test of and a posteriori Tukey test were used to analyse the differences between inoculation techniques. The time the fungus remains in the plant and the interaction between the two variables, was obtained using InfoStat (2007). Before data analysis, the Shapiro-Wilk test was used to assess data normality. The frequency of colonization expressed as a percentage was angularly transformed to stabilize the variance. The significance differences between treatments was measured by F-test $(P=0.05)$. Differences between mortality and reproduction of adults and nymphs between leaves inoculated and controls were evaluated using paired sample t-tests (Infostat, 2007). Corrected percent mortality was calculated using Abbott's formula (Abbott, 1925). Differences between controls and treatments in the feeding preference of aphids were evaluated using paired sample t-tests (Infostat, 2007).

\section{RESULTS}

Evaluation of Beauveria bassiana as an endophyte: There were significant differences between inoculation techniques $(\mathrm{F}=11.52$, df $=2,261, \mathrm{P}<0.0001)$. Leaf spraying showed the highest colonization frequency, followed by root dipping and seed immersion that showed significantly lower values. The time after inoculation did not differ significantly in the colonization of $B$. bassiana $(\mathrm{F}=0.36, \mathrm{df}=2,261, \mathrm{P}=$ 0.6985). However, as shown in Fig. 1, the interaction between the inoculation techniques and the time after inoculation showed significant differences $(\mathrm{F}=5.12$, $\mathrm{df}=4,261, \mathrm{P}=0.0005)$. The highest frequency of colonization $(10 \%)$ was obtained after 7 days with leaf spraying. No endophytic colonization of $B$. bassiana was recorded after 7 and 14 days using seed immersion. Likewise, using leaf spraying, the endophytic colonization of $B$. bassiana decreased with time, but this tendency was not observed for root dipping and seed immersion techniques (Fig. 1). In all the treatments, the inoculum used showed an average viability $>95 \%$.

Natural endophytes and in vitro evaluation of the antifungal activity of $B$. bassiana: From the leaves of pepper inoculated with $B$. bassiana were isolated and identified seven species of Ascomycota anamorphs: Acremonium sp., Aspergillus terreus (Thom \& Church, 1918; Aspergillaceae, Eurotiales), Chaetopsina sp., Chaetomium globosum (Kunze, 1817, Chaetomiaceae, Sordariales), Chaetomium cochliodes (Palliser, 1910, Chaetomiaceae, Sordariales), Penicillium sp. and Trichocladium pyriforme (Dixon, 1968, Chaetomiaceae, Sordariales). Leaf spraying showed the presence of five species of natural endophytes with low frequencies of occurrence and the highest frequency of B. bassiana. In this treatment, Acremonium sp. was recorded with the highest frequency at 7 days after inoculation (Fig. 2A). Unlike in root dipping $B$. bassiana, presented a low frequency and, natural endophytes showed the greatest number of species (six species) and the highest frequencies of colonization in this treatment. As shown in Fig. 2B, C. globosum and $T$. pyriforme had the highest frequencies and were recorded at 7,15 and 28 days after inoculation. Seed immersion presented the lowest number of natural endophytes with the lowest frequencies (Fig. 2C). The antifungal activity of the natural endophytes C. globosum, C. cochliodes, A. terreus, T. piriforme 


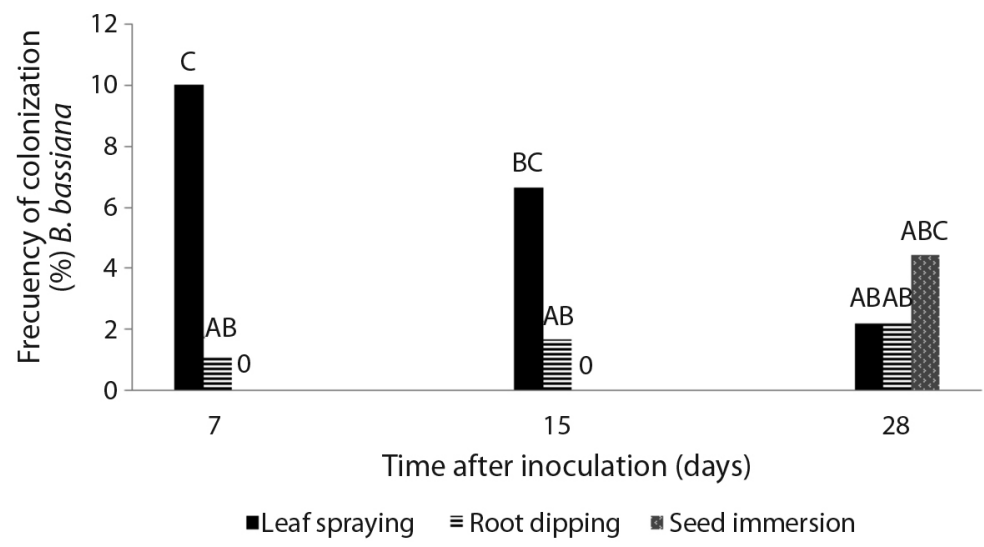

Fig. 1. Frequency of colonization (\%) of tomato leaf fragments at 7, 15 and 28 days after inoculation with Beauveria bassiana, using different inoculation techniques (leaf spraying, root dipping and seed immersion). Bars with different letters indicate differences of statistical significance according to Tukey's test $(\mathrm{p}<0.05)$.
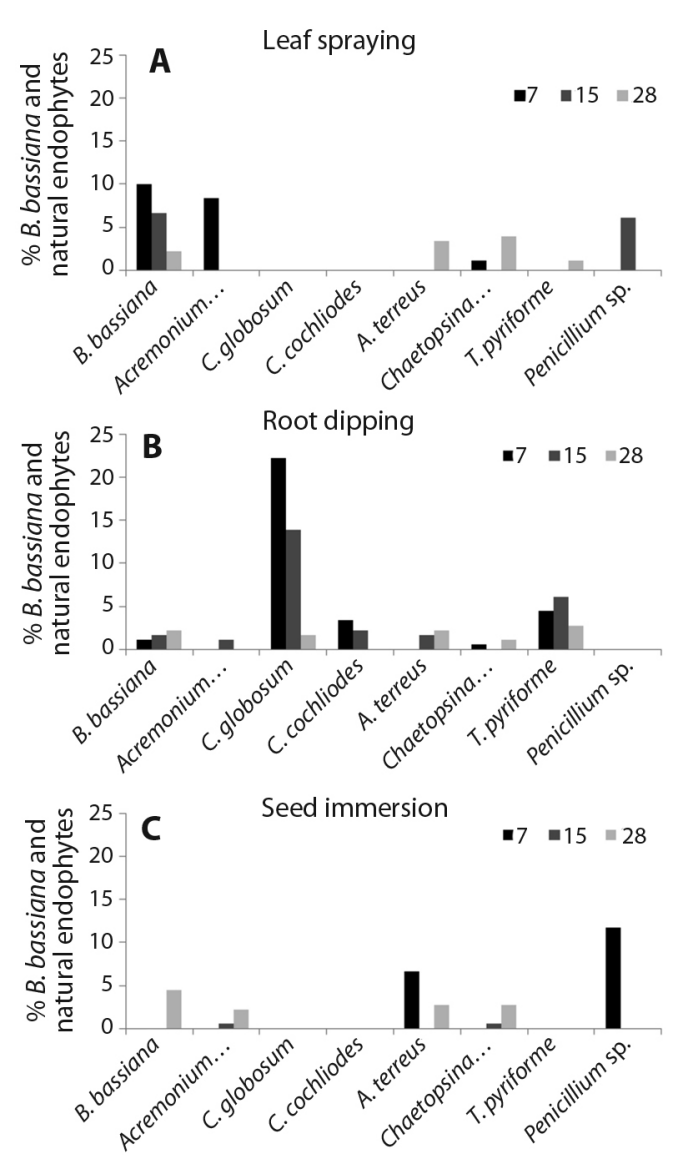

Fig. 2. Frequency of colonization (\%) of B. bassiana and of natural endophytes in the pepper leaf fragments at 7, 15 and 28 days after inoculation using A. leaf spraying, B. root dipping, and C. seed immersion. vs $B$. bassiana evaluated in vitro using the dual culture method, showed a low antifungal activity of $C$. globosum, $C$. cochliodes and $A$. terreus, and a moderate activity of $T$. piriforme against the entomopathogen.

Effect of $B$. bassiana as an endophyte on the aphid pest $M$. persicae: The mortality and reproduction of adults and nymphs did not show statistical significance differences between leaves inoculated with $B$. bassiana and controls (adults: $\mathrm{T}=0.75, \mathrm{df}=28, \mathrm{P}=0.45$ and nymphs: $\mathrm{T}=0.69, \mathrm{df}=28, \mathrm{P}=0.49$ ). However, the mortality of adults tended to increase and the offspring (nymphs) to decrease in the inoculated leaves. As shown in Fig. 3, of the 150 adult aphids used for each treatment, 85 did not survive in the inoculated leaves whereas the controls had 69 dead adults. A decrease in reproduction was also observed in the inoculated leaves, with 462 nymphs in the inoculated leaves and 510 nymphs in the controls.

The feeding preference of the aphids did not show significant differences between inoculated and control leaves $(\mathrm{T}=1.53, \mathrm{df}=58, \mathrm{P}=$ $0.13)$. However, a greater number of individuals was observed on the control leaves. Of 30 samples analysed, 16 samples preferred control (36 aphids), 12 samples preferred inoculated (26 aphids) and 2 samples were not considered. At 3, 4 and 5 days after inoculation, a greater 


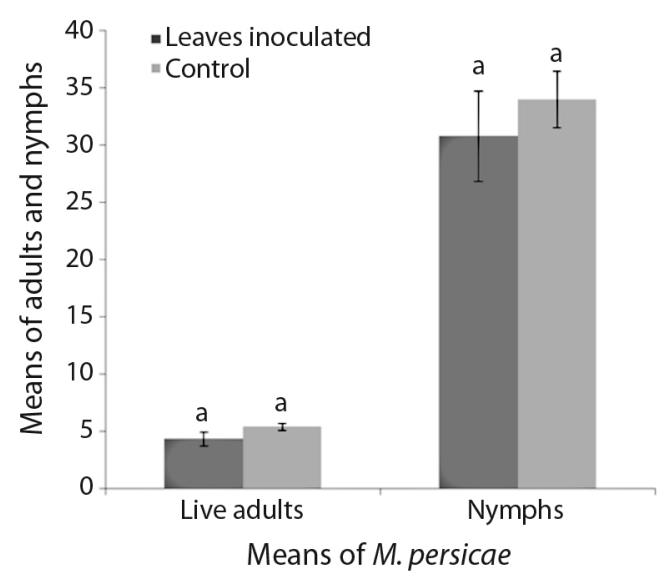

Fig. 3. Means number of $M$. persicae adults and nymphs recorded on inoculated and control leaves. The bars indicate SEM values (SE mean). Bars with different letters indicate differences of statistical significance according to $\mathrm{T}$ test $(\mathrm{P}<0.05)$.

number of aphids was observed on the control leaves, being this difference more marked at 3 days after inoculation. The means observed at 3,4 and 5 days after inoculation were $0.7,1.3$, 1.2 for inoculated leaves, respectively and 1.7, 1.4, 1.3 for control leaves, respectively (Fig. 4).

\section{DISCUSSION}

Plants can harbour endophytic fungi that might induce changes in their physiology and in turn affect their interaction with herbivorous insects. Previous studies have reported the presence of different species of entomopathogenic fungi that occur as natural endophytes within a limited range of plants. In the case of $B$. bassiana, many studies have reported its successful inoculation and re-isolation from various plants (Tefera \& Vidal, 2009), e.g. using foliar spraying in pepper (Mantzoukas \& Lagogiannis, 2019), potato (Wagner \& Lewis, 2000), and stem injection and foliar spraying in tomato (Allegrucci et al., 2017). However, Posada et al. (2007) observed that the leaves of some plants, such as coffee, have deficient entry routes for this fungus.

In this study, it was showed that the strain B. bassiana LPSC 1067 was established effectively as an endophyte in the pepper tissues and was re-isolated from new leaves at 7, 15 and 28 days after the inoculation using foliar spraying and root dipping. Beauveria bassiana was absent from control plants and surfacesterilized leaf washes (Gurunligappa et al., 2010). The ability of B. bassiana to establish in different plant tissues located far from the site of inoculation and its potential to move through them was evidenced by the presence of this fungus in the leaf fragments after the inoculation by root dipping and seed immersion. The most effective inoculation technique was leaf spraying and the highest colonization was recorded

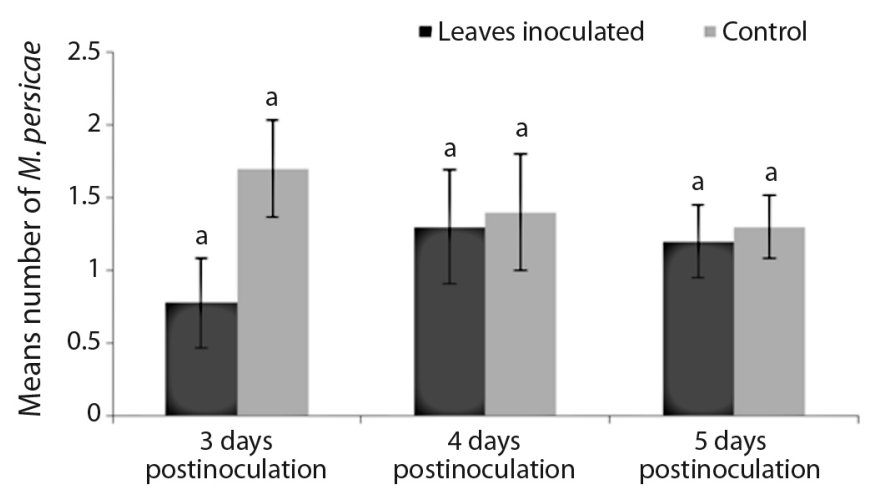

Means of M. persicae

Fig. 4. Mean number of individuals recorded on inoculated and control leaves at 3, 4 and 5 days after inoculation (10 repetitions). The bars indicate SEM values (standard error mean). Bars with different letters indicate differences of statistical significance according to $\mathrm{T}$ test $(\mathrm{P}<0.05)$. 
at 7 days after inoculation. The endophytic colonization, estimated by the frequency of $B$. bassiana after inoculation using this technique, decreased over time. This decrease in colonization over time might be either due to the immune response of the host towards the fungus, the expansion of leaves with the maintenance of the colonies that were already established or the possible competition with other endophytes in the plant (Posada et al., 2007).

Plants are able to recognize microbial compounds (fungal chitin) that are produced during pathogen attack and trigger defensive pathways (Zipfel, 2009; Newman, Sundelin, Nielsen, \& Erbs, 2013). Beneficial fungi and saprophytic pathogens have developed adaptive mechanisms, such as the secretion of effector proteins, to facilitate the evasion of plant defences and colonize the extracellular spaces of plant tissues (Van Esse, Bolton, Stergiopoulos, de Wit, \& Thomma, 2007). Schulz and Boyle (2005) described this interaction between the host plant and the endophyte as a balanced antagonism. In this study, it was observed that natural endophytes presented higher frequencies in the treatments in which the inoculated entomopathogen showed a low frequency. This might indicate the presence of antifungal activity, which interferes in the establishment of the entomopathogen in the plant tissue. Trichocladium piriforme was one of the most frequently recorded endophyte at 7, 15 and 28 days after the inoculation using root dipping, and showed a moderate antifungal activity against B. bassiana. Therefore, the presence of this endophyte in the pepper tissues appears to interfere in the establishment of B. bassiana. Evueh and Ogbebor (2008) described a significant interaction was exhibited by Trichocladium sp. in which the growth of Colletotrichum gloeosporioides was much affected by hyphal interference. The antagonistic fungus grew over the colony of C. gloeosporioides and completely inhibited its growth. Regarding the effect of the endophytic $B$. bassiana on the aphid pest $M$. persicae, we did not find significant differences in the mortality and reproduction of adults and nymphs between treatments and controls. However, the adult mortality tended to increase and the offspring (nymphs) to decrease in the inoculated leaves. These results are in accordance with similar studies performed by Clifton, Jaronski, Coates, Hodgson, and Gassmann (2018) where no significant effects on survival and reproduction of the aphid Aphis glycines were observed with $B$. bassiana as endophyte. On the other hand, these results contrast to those found by Mantzoukas and Lagogiannis (2019), who described a high percentage of mortality of $M$. persicae on pepper leaves with endophytic $B$. bassiana after 21 days. Probably these differences could be related to the origin of the $B$ bassiana strain. B. bassiana strain LPSC 1067 used in this study was isolated from an orthopteran insect. There are several studies showing that strains pathogenicity is variable and has a direct relationship with the insect species host that was originally isolated (Muñoz, De la Rosa, \& Toledo, 2009, Hernández Díaz-Ordaz, Pérez, \& Toledo, 2010).

No differences of statistical significance were found in the feeding preference of M. persicae between inoculated and control leaves, although a greater number of aphids was observed on control leaves, being this number higher at 3 days than at 4 and 5 days after inoculation. Previous research has suggested that $B$. bassiana can induce plant defences, which in turn suppress insects (McKinnon, Saari, Moran-Diez, Meyling, Raad, \& Glare, 2017). Future studies evaluating the indirect effects of endophytic entomopathogens on both plants and herbivorous insects are needed to further explore their potential use in the management of insect pests, as well as studies to assess the entomopathogenic activity of natural endophytes. Although the ecology and potential applied value of the specific interactions between plants, fungi, and insects have not yet been explored, the use of entomopathogens as endophytes opens interesting possibilities for the specific control of some insect pests.

Ethical statement: authors declare that they all agree with this publication and made 
significant contributions; that there is no conflict of interest of any kind; and that we followed all pertinent ethical and legal procedures and requirements. All financial sources are fully and clearly stated in the acknowledgements section. A signed document has been filed in the journal archives.

\section{ACKNOWLEDGMENTS}

We thank Proyecto de Investigación Orientado (PIO-CONICET-UNLP) 2017-2018, and Universidad Nacional de La Plata (11/N 773) for partially supporting this investigation.

\section{RESUMEN}

Establecimiento del hongo entomopatógeno Beauveria bassiana como endófito en Capsicum annuum y sus efectos sobre la plaga del áfido Myzus persicae (Homoptera: Aphididae). Introducción: Los hongos entomopatógenos se han utilizado como agentes de control biológico de plagas de insectos y han demostrado una capacidad prometedora para colonizar una amplia gama de especies de plantas como endófitos. Objetivo: Los objetivos de este estudio fueron: evaluar las técnicas de inoculación más efectivas para $B$. bassiana en plantas de pimiento; evaluar la presencia de endófitos naturales y su interacción con B. bassiana y evaluar el efecto de B. bassiana sobre la preferencia de alimentación de la hoja de pimiento y el crecimiento de la plaga de áfidos $M$. persicae. Métodos: Se evaluaron tres técnicas de inoculación: aspersión foliar, inmersión de semillas e inmersión de raíces. Las plantas de pimiento se inocularon con una suspensión de conidias ajustada a $1 \times 10^{8}$ conidias $/ \mathrm{ml}$. La presencia de $B$. bassiana en las plántulas se evaluó a los 7, 15 y 28 días después de la inoculación. Resultados: Se encontraron diferencias significativas entre las técnicas de inoculación. La aspersión foliar mostró la frecuencia más alta. Los endófitos naturales presentaron frecuencias más altas en los tratamientos en los que $B$. bassiana tuvo una frecuencia baja, esto podría indicar la presencia de actividad antifúngica que interfiere con el establecimiento del entomopatógeno en los tejidos de pimiento. No se encontraron diferencias significativas en la mortalidad, reproducción y preferencia alimentaria de $M$. persicae. Conclusiones: Se demostró que la cepa B. bassiana LPSC 1067 se estableció efectivamente como endófito en los tejidos de pimiento. La técnica de inoculación más efectiva fue la aspersión foliar. No se encontraron diferencias significativas con respecto a la mortalidad, reproducción y preferencia alimentaria de $M$. persicae. Sin embargo, la inoculación con $B$. bassiana mostró una tendencia a aumentar la mortalidad de los adultos y a disminuir la descendencia (ninfas). Se necesitan estudios futuros que evalúen los efectos indirectos de los entomopatógenos endofíticos tanto en plantas como en insectos herbívoros para explorar más a fondo su posible uso en el manejo de insectos plaga.

Palabras clave: hongos endófitos; técnicas de inoculación; agentes de control biológico; pulgones; áfidos.

\section{REFERENCES}

Abbot, W.S. (1925). A method for computing the effectiveness of an insecticide. Journal of Economic Entomology, 18, 265-267.

Akello, J., Dubois, T., Gold, C.S., Coyne, D., Nakavuma, J., \& Paparu, P. (2007). Beauveria bassiana (Balsamo) Vuillemin as an endophyte in tissue culture banana (Musa spp.). Journal of Invertebrate Patho$\log y, 96(1), 34-42$.

Allegrucci, N., Velazquez, M.S., Russo, M.L., Perez, E., \& Scorsetti, A.C. (2017). Endophytic colonisation of tomato by the entomopathogenic fungus Beauveria bassiana: the use of different inoculation techniques and their effects on the tomato leafminer Tuta absoluta (Lepidoptera: Gelechiidae). Journal of Plant Protection Research, 57(4), 205-211.

Arnold, A.E., Maynard, Z., \& Gilbert, G.S. (2001). Fungal endophytes in dicotyledonous neotropical trees: patterns of abundance and diversity. Mycological Research, 105(12), 1502-1507.

Blackman, R.L., \& Eastop, V.F. (2000). Aphids on the world's crops, an identification and information guide. Chichester, UK: John Wiley \& Sons Ltd.

Brownbridge, M., Reay, S.D., Nelson, T.L., \& Glare, T.R. (2012). Persistence of Beauveria bassiana (Ascomycota: Hypocreales) as an endophyte following inoculation of radiata pine seed and seedlings. Biological Control, 61, 194-200.

Chen, C., Li, Z.Y., \& Feng, M.G. (2008). Occurrence of entomopathogenic fungi in migratory alate aphids in Yunnan Province of China. BioControl, 53, 317-326.

Clifton, E.H., Jaronski, S.T., Coates, B.S, Hodgson, E.W., \& Gassmann, A.J. (2018). Effects of endophytic entomopathogenic fungi on soybean aphid and identification of Metarhizium isolates from agricultural fields. PLoS ONE, 13(3), 1-19.

Crawford, K.M., Land, J.M., \& Rudgers, J.A. (2010). Fungal endophytes of native grasses decrease insect herbivore preference and performance. Oecologia, 164(2), 431-444.

Devonshire, A.L., Field, L.M., Foster, S.P., Moores, G.D., Williamson, M.S., \& Blackman, R.L. (1998). The evolution of insecticide resistance in the peachpotato aphid, Myzus persicae. Philosophical 
Transactions of the Royal Society B: Biological Sciences, 353(1376), 1677-1684.

Dixon, M. (1968). Trichocladium pyriformis sp. nov. Transactions of the British Mycological Society, 51(1), 160-164.

Domsch, K.H., Gams, W., \& Anderson, T.H. (2007). Compendium of soil fungi. London, UK: Academic Press.

Evueh, G.A., \& Ogbebor, N.O. (2008). Use of phylloplane fungi as biocontrol agent against Colletotrichum leaf disease of rubber (Hevea brasiliensis Muell. Arg.). African Journal of Biotechnology, 7(15), 2569-2572.

Goettel, M.S., \& Inglis, G.D. (1997). Fungi: hyphomycetes. In L. Lacey (Ed.), Manual of techniques in insect pathology (pp. 213-249). London, UK: Academic Press.

Gomez-Vidal, S., Lopez-Llorca, L.V., Jansson, H.B., \& Salinas, J. (2006). Endophytic colonization of date palm (Phoenix dactylifera L.) leaves by entomopathogenic fungi. Micron, 37, 624-632.

Gurulingappa, P., Sword, G.A., Murdoch, G., \& McGee, P.A. (2010). Colonization of crop plants by fungal entomopathogens and their effects on two insect pests when in planta. Biological Control, 55, 34-4.

Hernández Díaz-Ordaz, N., Pérez, N., \& Toledo, J. (2010). Patogenicidad de tres cepas de hongos entomopatógenos a adultos de Anastrepha obliqua (Macquart) (Diptera: Tephritidae) en condiciones de laboratorio. Acta Zoológica Mexicana, 26(3), 481-494.

InfoStat. (2007). User's Manual (Version 1). Córdoba: Universidad Nacional de Córdoba.

Jaber, L.R., \& Enkerli, J. (2017). Fungal entomopathogens as endophytes: can they promote plant growth? Biocontrol Science and Technology, 27, 28-41.

Jaber, L.R., \& Ownley, B.H. (2018). Can we use entomopathogenic fungi as endophytes for dual biological control of insect pests and plant pathogens? Biological Control, 116, 36-45.

Jones, K.D. (1994). Aspects of the biology and biological control of the European corn borer in North Carolina (Doctoral dissertation). North Carolina University, Raleigh, NC, USA.

Manoussopoulos, Y., Mantzoukas, S, Lagogiannis, I., Goudoudaki, S., \& Kambouris, M. (2019). Effects of Three Strawberry Entomopathogenic Fungi on the Prefeeding Behavior of the Aphid Myzus persicae. Journal of Insect Behavior, 32, 99-108.

Mantzoukas, S., Chondrogiannis, C.H., \& Grammatikopoulos, G. (2015). Effects of three endophytic entomopathogens on sweet sorghum and on the larvae of the stalk bored Sesamia nonagrioides. Entomologia Experimentalis et Applicata, 154(1), 78-87.

Mantzoukas, S., \& Lagogiannis, I. (2019). Endophytic Colonization of Pepper (Capsicum annum) Controls Aphids (Myzus persicae Sulzer). Applied Science, 9, 2239.

McKinnon, A.C., Saari, S., Moran-Diez, M.E., Meyling, N.V., Raad, M., \& Glare, T.R. (2017). Beauveria bassiana as an endophyte: a critical review on associated methodology and biocontrol potential. BioControl, $62,1-17$.

Muñoz, J.A., De la Rosa, W., \& Toledo, J. (2009). Mortalidad de Ceratitis capitata (Wiedemann) (Diptera: Tephritidae) por diversas cepas de Beauveria bassiana (Bals.) Vuillemin, en condiciones de laboratorio. Acta Zoológica Mexicana, 25(3), 609-624.

Newman, M.A., Sundelin, T., Nielsen, J.T., \& Erbs, G. (2013). MAMP (microbe-associated molecular pattern) triggered immunity in plants. Frontiers in Plant Science, 4, 1-14.

Ownley, B.H., Griffin, M.R., Klingeman, W.E., Gwinn, K.D., Moulton, J.K., \& Pereira, R.M. (2008). Beauveria bassiana: Endophytic colonization and plant disease control. Journal of Invertebrate Pathology, 98, 267-270.

Pampapathy, G., Gregory, A., Sword, A., Gregory, M., Peter, A., \& McGee, A. (2010). Colonization of crop plants by fungal entomopathogens and their effects on two insect pests when in planta. Biological Control, 55, 34-41.

Paul, N.C., Deng, J.X., Sang, H.K., Choi, Y.P., \& Yu, S.H. (2012). Distribution and antifungal activity of endophytic fungi in different growth stages of chili pepper (Capsicum annuum L.) in Korea. Plant Pathology Journal, 28(1), 10-19.

Pelizza, S.A., Elíades, L.A., Saparrat, M.C.N., Cabello, M.N., Scorsetti, A.C., \& Lange, C.E. (2012). Screening of argentine native fungal strains for biocontrol of the grasshopper Tropidacris collaris: relationship between fungal pathogenicity and chitinolytic enzyme activity. World Journal of Microbiology and Biotechnology, 28(4), 1359-1366.

Perry, L., Dickau, R., Zarrillo, S., Holst, I., Pearsall, D.M., Piperno, D.R., \& Raymond, J.S. (2007). Starch fossils and the domestication and dispersal of chili peppers (Capsicum spp. L.) Americas Science, 315(5814), 986-988.

Petrini, O., \& Fisher, P.J. (1986). Fungal endophytes in Salicornia perennis. Transactions of the British Mycological Society, 87(4), 647-651.

Posada, F., Aime, M.C., Peterson, S.W., Rehner, S.A., $\&$ Vega, F.E. (2007). Inoculation of coffee plants with the fungal entomopathogen Beauveria bassiana (Ascomycota: Hypocreales). Mycological Research, 111(6), 748-757. 
Posada, F., \& Vega, F.E. (2005). Establishment of the fungal entomopathogen Beauveria bassiana (Ascomycota: Hypocreales) as an endophyte in cocoa seedlings (Theobroma cacao). Mycologia, 97, 1195-1200.

Rozin, P., \& Schiller, D. (1980). The nature and acquisition of a preference for chili pepper by humans. Motivation and Emotion, 4(1), 77-101.

Russo, M.L., Pelizza, S.A., Cabello, M.N., Stenglein, S.A., \& Scorsetti, A.C. (2015). Endophytic colonisation of tobacco, corn, wheat and soybeans by the fungal entomopathogen Beauveria bassiana (Ascomycota, Hypocreales). Biocontrol Science and Technology, $25,475-480$.

Russo, M.L., Scorsetti, A.C.,Vianna, M.F., Allegrucci, N., Ferreri, N.A., Cabello, M.N., \& Pelizza, S.A. (2018). Effects of endophytic Beauveria bassiana (Ascomycota: Hypocreales) on biological, reproductive parameters and food preference of the soybean pest Helicoverpa gelotopoeon. Journal of King Saud University, 31(4), 1077-1082.

Schulz, B, \& Boyle, C. (2005). The endophytic continuum. Mycological Research, 109, 661-686.

Taechowisan, T., Peberdy, J.F., \& Lumyong, S. (2003) Isolation of endophytic actinomycetes from selected plants and their antifungal activity. World Journal of Microbiology and Biotechnology, 19(4), 381-385.
Tefera, T., \& Vidal, S. (2009). Effect of inoculation method and plant growth medium on endophytic colonization of sorghum by the entomopathogenic fungus Beauveria bassiana. BioControl, 54, 663-669.

Thom, C., \& Church, M.B. (1918). Aspergillus fumigatus, A. nidulans, $A$. terreus n. sp. and their allies. American Journal of Botany, 5(2), 84-104.

Van Esse, H.P., Bolton, M.D., Stergiopoulos, I., de Wit, P.J., \& Thomma, B.P. (2007). The chitin-binding Cladosporium fulvum effector protein Avr4 is a virulence factor. Molecular Plant-Microbe Interactions, 20, 1092-1101.

Vega, F.E. (2008). Insect pathology and fungal endophytes. Journal of Invertebrate Pathology, 98(3), 277-279.

Wagner, B.L., \& Lewis, L.C. (2000). Colonization of corn, Zea mays, by the entomopathogenic fungus Beauveria bassiana. Applied and Environmental Microbiology, 66(8), 3468-3473.

Wilson, D. (1995). Endophyte: the evolution of a term, and clarification of its use and definition. Oikos, 73, 274-276.

Zipfel, C. (2009). Early molecular events in PAMP-triggered immunity. Current Opinion in Plant Biology, $12,414-420$. 